\title{
Analisis Persepsi Pengguna Lajur Khusus Sepeda Motor (Studi Kasus: Jalan Medan Merdeka Barat, DKI Jakarta)
}

\author{
M. Vikry M. Septiansyah ${ }^{1}$; Dwi Novi Wulansari ${ }^{2}$ \\ ${ }^{1,2}$ Universitas 17 Agustus 1945 Jakarta \\ ${ }^{1}$ muhammadvikry1@gmail.com
}

\begin{abstract}
Special lanes for motorbikes located on Jalan Medan Merdeka Barat, DKI Jakarta are intended to reduce the level of traffic congestion and reduce the incidence of motorcycle accidents. The purpose of this study is to evaluate the performance of a special lane of a motorcycle based on user perception. Analysis of user perceptions is done using questionnaire survey data using the Importance Performance Analysis (IPA) method. Data from the questionnaire survey were used as many as 100 respondent data along the road. Based on the results of the analysis it can be seen that the performance of the motorcycle special lane has not met the expectations of the lane users. That is because there are still side barriers on motorbike lanes, such as vehicles parked and vehicles that stop at these lanes.
\end{abstract}

Keywords: Special Lane, Motorcycle, Importance Performance Analysis

\begin{abstract}
ABSTRAK
Lajur khusus sepeda motor yang berlokasi di Jalan Medan Merdeka Barat, DKI Jakarta dimaksudkan untuk mengurangi tingkat kemacetan lalulintas dan mengurangi kejadian kecelakaan sepeda motor. Tujuan penelitian ini adalah untuk mengevaluasi kinerja lajur khusus sepeda motor berdasarkan persepsi pengguna. Analisis persepsi pengguna dilakukan menggunakan data hasil survey kuesioner menggunakan metode Importance Peroformance Analysis (IPA). Data hasil survey kuesioner yang digunakan sebanyak 100 data responden yang berada disepanjang jalan tersebut. Berdasarkan hasil analisis dapat diketahui bahwa kinerja lajur khusus sepeda motor tersebut belum memenuhi harapan dari pengguna lajur tersebut. Hal tersebut dikarenakan masih adanya hambatan samping pada lajur khusus sepeda motor, seperti kendaraan yang parkir dan kendaraan yang berhenti pada lajur tersebut.
\end{abstract}

Kata kunci: Lajur Khusus, Sepeda Motor, Importance Peroformance Analysis 


\section{PENDAHULUAN}

Lajur khusus sepeda motor telah diberlakukan dan diterapkan dibeberapa negara berkembang, termasuk di Indonesia. Lajur khusus sepeda motor diharapkan tidak hanya mengurangi kemacetan lalu lintas yang diakibatkan gerakan manuver sepeda motor, tetapi juga meningkatkan keselamatan para pengendara sepeda motor. Dalam pergerakannya, sepeda motor cenderung tidak mengikuti lajur yang sama sehingga mengakibatkan terganggunya kendaraan yang lain dan berpotensi menimbulkan konflik lalu lintas yang tidak jarang berujung menjadi sebuah kecelakaan lalu lintas. Permasalahan tersebut juga terjadi di ruas Jalan Medan Merdeka Barat, DKI Jakarta.

Pada penelitian mengenai kinerja ruas Jalan Medan Merdeka Barat, DKI Jakarta dapat diketahui bahwa tingkat pelayanan ruas (LOS) Jalan Medan Merdeka Barat dengan arus lalu lintas dari arah utara adalah LOS D dengan nilai V/C ratio 0,84 dan kecepatan rata-rata sebesar $48 \mathrm{~km} / \mathrm{jam}$. Sedangkan tingkat pelayanan ruas Jalan Medan Merdeka Barat dengan arus lalu lintas dari arah selatan adalah LOS C dengan nilai V/C ratio 0,45 dan kecepatan rata-rata sebesar $41 \mathrm{~km} / \mathrm{jam} \mathrm{[1].}$ Berdasarkan tingkat kinerja ruas jalan yang masih rendah tersebut dapat disimpulkan bahwa lajur khusus sepeda motor di Jalan Medan Merdeka Barat, DKI Jakarta tidak efektif.

Evaluasi efektifitas implementasi lajur khusus sepeda motor pada ruas Jalan Medan Merdeka Barat, DKI Jakarta dilakukan untuk mengetahui penyebab tidak efektifnya lajur, dimana efektifitas ditinjau dari persepsi pengguna lajur khusus sepeda motor. Analisis persepsi pengguna lajur khusus sepeda motor dilakukan berdasarkan data survey kuesioner menggunakan metode Importance Peroformance Analysis (IPA).

\section{METODE PENELITIAN}

\subsection{Importance Performance Analysis (IPA)}

Importance-Performance Analysis merupakan metode pengukuran kepuasan klien dengan suatu produk atau layanan [2]. Pendekatan IPA mengakui kepuasan sebagai fungsi dari dua komponen, yaitu tingkat kepentingan suatu produk atau layanan kepada klien dan kinerja bisnis dalam menyediakan layanan atau produk tersebut. Metode IPA memerlukan pengukuran tingkat kesesuaian untuk mengetahui seberapa besar pengguna merasa puas terhadap kinerja penyedia jasa, dan seberapa besar pihak penyedia jasa memahami apa yang diinginkan pengguna terhadap jasa yang mereka berikan. Rumus untuk mengetahui tingkat kesesuaian adalah sebagai berikut:

$T_{k}=\frac{X}{Y} \times 100 \%$

Dengan: $\mathrm{Tk}=$ Tingkat kesesuaian responden, $\mathrm{X}=$ Skor penilaian pelaksanaan kinerja penyedia jasa, $\mathrm{Y}=$ Skor penilaian kepentingan pengguna jasa (konsumen)

Pada analisis Importance-Performance Analysis, dilakukan pemetaan menjadi 4 kuadran untuk seluruh atribut yang mempengaruhi kualitas pelayanan. Pembagian kuadran dalam ImportancePerformance Analysis ditampilkan pada Gambar 1. 


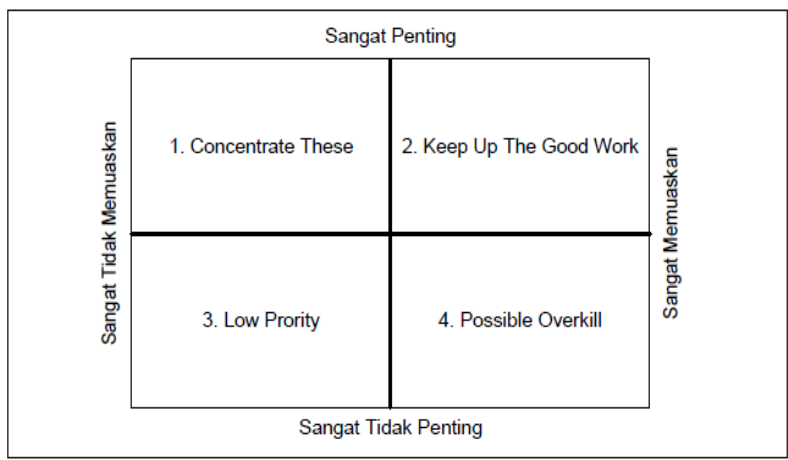

Gambar 1. Diagram Kartesius Importance Performance Analysis

Penjelasan mengenai keempat kuadran yang terdapat pada diagram kartesius IPA sebagai berikut:

1. Kuadran I (Concentrate These)

adalah bagian yang memuat faktor-faktor yang dianggap penting oleh pengguna, tetapi pada kenyataannya faktor-faktor ini belum sesuai dengan harapan pengguna, dimana tingkat kepuasan yang diperoleh masih rendah. Atribut-atribut yang masuk dalam kuadran ini harus ditingkatkan.

2. Kuadran II (Keep Up The Good Work) adalah bagian yang memuat faktor-faktor yang dianggap penting oleh pengguna, dan faktor-faktor yang dianggap pengguna sudah sesuai dengan yang dirasakannya sehingga tingkat kepuasannya relatif lebih tinggi. Atribut-atribut yang masuk dalam kuadran ini harus tetap dipertahankan karena semua atribut ini menjadikan atribut yang penting bagi pengguna.

3. Kuadran III (Low Priority)

adalah bagian yang memuat faktor-faktor yang dianggap kurang penting oleh pengguna, dan pada kenyatannya kinerjanya tidak terlalu istimewa. Peningkatan atribut-atribut yang termasuk dalam kuadran ini dapat dipertimbangkan kembali karena pengaruhnya terhadap manfaat yang dirasakan oleh pengguna sangat kecil.

4. Kuadran IV (Possible Overkill) adalah bagian yang memuat faktor-faktor yang dianggap kurang penting oleh pengguna, dan dirasakan terlalu berlebihan. Atribut-atribut yang termasuk dalam kuadran ini dapat dikurangi agar penyedia jasa dapat menghemat biaya.

Tingkat kepentingan suatu atribut dinilai dengan menggunakan skala 5 tingkat (likert) yang terdiri dari sangat penting, cukup penting, kurang penting dan tidak penting. Kelima penilaian tersebut diberikan bobot sebagai berikut:

a. Pilihan sangat penting memiliki bobot nilai 5

b. Pilihan penting memiliki bobot nilai 4

c. Pilihan cukup penting memiliki bobot nilai 3

d. Pilihan kurang penting memiliki bobot nilai 2

e. Pilihan tidak penting memiliki bobot nilai 1

Untuk kinerja/kepuasan diberikan lima penilaian dengan bobot sebagai berikut:

a. Pilihan sangat setuju memiliki bobot nilai 5 yang berarti masyarakat sangat puas

b Pilihan setuju memiliki bobot nilai 4 yang berarti masyarakat puas 
c. Pilihan cukup setuju memiliki bobot nilai 3, berarti masyarakat cukup puas

d. Pilihan kurang setuju memiliki bobot nilai 2 yang berarti masyarakat kurang puas

e. Pilihan tidak setuju memiliki bobot nilai 1 yang berarti masyarakat tidak puas

Penentuan ukuran data kuesioner untuk mengetahui persepsi pengguna jalan khusus sepeda motor dilakukan sebanyak 100 responden [6], sebagai berikut:

$n=\frac{N}{1+N e^{2}}$

Dimana n: jumlah sampel, N: jumlah populasi, dan e: batas toleransi kesalahan (error tolerance).

\subsection{Uji Validitas}

Validitas adalah ketepatan atau kecermatan suatu instrument dalam pengukuran. Pengujian validitas konstruk dilakukan dengan cara mengkorelasikan antara skor butir pertanyaan dengan skor totalnya [3]. Teknik yang sering digunakan untuk uji validitas adalah menggunakan korelasi Bivariate Pearson. Analisis ini dilakukan dengan mengkorelasikan antara masing-masing skor atribut dengan skor total. Skor total adalah penjumlahan dari keseluruhan atribut yang ada. Atributatribut pertanyaan yang berkorelasi signifikan dengan skor total menunjukkan atribut-atribut tersebut mampu memberi dukungan dalam mengungkap apa yang ingin diungkap, rumus korelasi produk momen yang digunakan:

$\mathrm{r}_{\mathrm{xy}}=\frac{n \sum x_{i} y_{i}-\left(\sum x_{i}\right)\left(\sum y_{i}\right)}{\sqrt{\left(n \sum x i^{2}\right)-\left(\sum x i\right)^{2}\left(n \sum y i^{2}-\left(\sum y i\right)^{2}\right)}}$

Keterangan:

$\mathrm{r}_{\mathrm{xy}} \quad=$ Koefisien korelasi

$\mathrm{n} \quad=$ Jumlah responden

$\Sigma \mathrm{x} \quad=$ Jumlah skor atribut

$\Sigma \mathrm{y} \quad=$ Jumlah skor total

$\Sigma \mathrm{x}^{2} \quad=$ Jumlah kuadrat skor atribut

$\Sigma \mathrm{y}^{2} \quad=$ Jumlah kuadrat skor total

$\Sigma \mathrm{xy} \quad=$ Total perkalian skor atribut

Nilai $r$ hitung dicocokkan dengan $r$ tabel product moment pada taraf signifikan. Jika lebih besar dari $r$ tabel, maka butir soal tersbut dapat dinyatakan valid.

\subsection{Uji Reliabilitas}

Reliabilitas berhubungan dengan tingkat ketetapan dari hasil pengukuran [4]. Kuesioner dikatakan reliabel jika dapat memberikan hasil relatif sama (ajeg) pada saat dilakukan pengukuran kembali pada obyek yang berlainan pada waktu yang berbeda atau memberikan hasil yang tetap. Untuk mengukur reliabilitas kuesioner dapat digunakan rumus Cronbach's Alpha sebagai berikut:

$\boldsymbol{r}_{\mathbf{1 1}}=\left[\frac{\boldsymbol{K}}{(\boldsymbol{k}-\mathbf{1})}\right]\left[1-\frac{\sum \sigma_{b^{2}}}{\sigma_{t^{2}}}\right]$ 


\section{Keterangan:}

$\mathrm{r}_{11}=$ Reliabilitas instrumen

$\Sigma \sigma_{\mathrm{b}}{ }^{2}=$ Jumlah varians butir

$\mathrm{K}=$ Banyaknya butir instrumen

$\Sigma \sigma_{\mathrm{t}}^{2}=$ Varians total

Kategori koefisien reliabilitas [5] adalah sebagai berikut:

$0,90<\mathrm{r}_{11} \leq 1,00$ reliabilitas sangat tinggi

$0,70<\mathrm{r}_{11}<0,90$ reliabilitas tinggi

$0,40<\mathrm{r}_{11}<0,70$ reliabilitas sedang

$0,20<\mathrm{r}_{11}<0,40$ reliabilitas rendah

$\mathrm{r}_{11} \leq 0,20$ reliabilitas sangat rendah (tidak reliable)

\section{HASIL DAN PEMBAHASAN}

Data karakteristik responden ditampilkan pada tabel berikut.

Tabel 1. Data Karakteristik Responden

\begin{tabular}{|c|c|c|}
\hline No & Data Karakteristik Responden & Presentase \\
\hline 1 & $\begin{array}{ll}\text { Jenis } & \text { Kelamin } \\
\text { a. } & \text { Laki-laki } \\
\text { b. } & \text { Perempuan }\end{array}$ & $\begin{array}{l}75 \% \\
25 \%\end{array}$ \\
\hline 2 & $\begin{array}{l}\text { Usia } \\
\qquad \begin{array}{l}\text { a. } \leq 16 \text { tahun } \\
\text { b. } 17-50 \text { tahun } \\
\text { c. } \geq 51 \text { tahun }\end{array}\end{array}$ & $\begin{array}{l}0 \% \\
81 \% \\
19 \%\end{array}$ \\
\hline 3 & 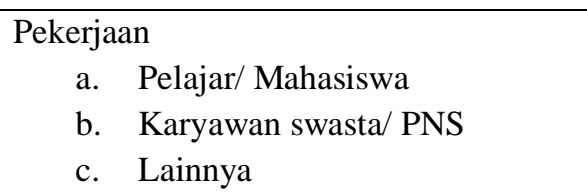 & $\begin{array}{l}13 \% \\
74 \% \\
13 \%\end{array}$ \\
\hline 4 & 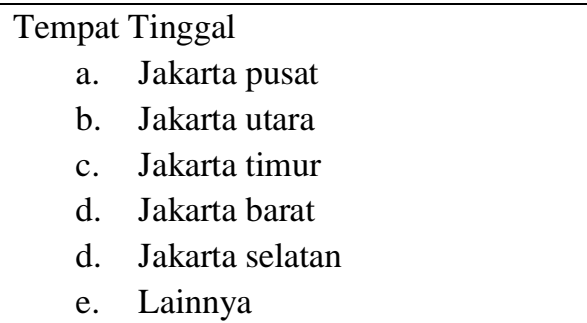 & $\begin{array}{c}25 \% \\
8 \% \\
6 \% \\
10 \% \\
39 \% \\
12 \%\end{array}$ \\
\hline 5 & $\begin{aligned} & \text { Pendapatan perbulan } \\
& \text { a. } \leq \text { Rp. } 1.000 .000 \\
& \text { b. } \text { Rp. } 1.000 .000-3.000 .000 \\
& \text { c. } \text { Rp. } 3.000 .000-5.000 .000 \\
& \text { d. } \text { Rp. } 5.000 .000-7.000 .000 \\
& \text { e. } \text { Rp. } 7.000 .000-9.000 .000 \\
& \text { f. } \geq \text { Rp. } 9.000 .000\end{aligned}$ & $\begin{array}{l}9 \% \\
32 \% \\
43 \% \\
14 \% \\
2 \% \\
0 \%\end{array}$ \\
\hline 6 & 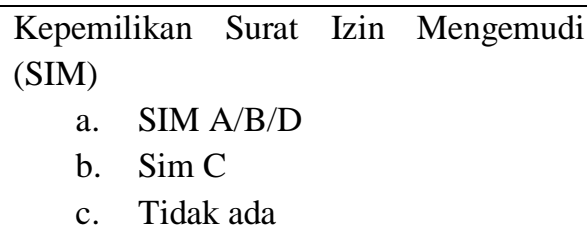 & $\begin{array}{l}18 \% \\
64 \% \\
18 \%\end{array}$ \\
\hline
\end{tabular}




\begin{tabular}{|c|c|c|}
\hline No & Data Karakteristik Responden & Presentase \\
\hline 7 & Mengendarai Mobil Per-Bulan & \\
& a. Tidak pernah & $82 \%$ \\
& b. 1-4 Kali & $9 \%$ \\
& c. 5-8 Kali & $3 \%$ \\
& d. $\geq 9$ Kali & $6 \%$ \\
\hline 8 & Mengendarai Motor Per-Bulan & $18 \%$ \\
& a. Tidak pernah & $8 \%$ \\
& b. 1-4 Kali & $5 \%$ \\
& c. 5-8 Kali & $69 \%$ \\
\hline
\end{tabular}

Uji validitas dilakukan dengan mengkorelasikan hasil jawaban tiap butir pernyataan dengan nilai total dari 100 responden, selanjutnya menentukan $r$ hitung. Jika $r$ hitung lebih besar dari pada $r$ tabel, maka butir pernyataan/atribut tersebut dinyatakan valid. Pada pengujian ini digunakan nilai signifikan $=2,5 \%, \mathrm{n}=100$, maka $\mathrm{r}$ tabel ditentukan sebesar 0,1966 .

Tabel 2. Uji validitas pernyataan penilaian kinerja terhadap lajur khusus sepeda motor

\begin{tabular}{|c|l|c|c|}
\hline No & \multicolumn{1}{|c|}{ Pernyataan/Atribut } & r hitung & Hasil \\
\hline 1 & $\begin{array}{l}\text { Lebar Lajur Khusus Sepeda Motor yang dapat Menampung volume } \\
\text { lalu lintas kendaraan, Khususnya sepeda motor }\end{array}$ & 0,6627 & Valid \\
\hline 2 & $\begin{array}{l}\text { Lebar Lajur khusus sepeda motor yang dapat dipergunakan untuk } \\
\text { menyiap satu sepeda motor }\end{array}$ & 0,6480 & Valid \\
\hline 3 & $\begin{array}{l}\text { Tersedia rambu dan marka lalu lintas berupa informasi lokasi masuk- } \\
\text { keluar sepeda motor, batas kecepatan, rambu larangan berhenti dan } \\
\text { parkir pada lokasi-lokasi tertentu }\end{array}$ & 0,7361 & Valid \\
\hline 4 & $\begin{array}{l}\text { Rambu dan marka lalu lintas dipasang pada tempat-tempat yang } \\
\text { diperlukan dan mudah diperlihatkan }\end{array}$ & 0,8420 & Valid \\
\hline 5 & $\begin{array}{l}\text { Tersedia pemisah (separator) antara ajur khusus sepeda motor dari } \\
\text { jalan utama berupa marka lalu lintas atau kereb }\end{array}$ & 0,7841 & Valid \\
\hline 6 & $\begin{array}{l}\text { Kecepatan sepeda motor dapat mencapai 40 Km/Jam pada lajur } \\
\text { khusus sepeda motor }\end{array}$ & 0,8433 & Valid \\
\hline 7 & $\begin{array}{l}\text { Tidak terdapat jam-jam khusus (pembatasan) pelaksanaan lajur } \\
\text { khusus sepeda motor }\end{array}$ & 0,5892 & Valid \\
\hline 8 & $\begin{array}{l}\text { Tidak terjadi selip pada saat jaan basah atau ketika melewati penutup } \\
\text { lubang jalan }\end{array}$ & 0,7366 & Valid \\
\hline 9 & Tersedia pembatas lajur khusus sepeda motor (guard rail) & 0,5122 & Valid \\
\hline 10 & $\begin{array}{l}\text { Tidak terdapat hambatan samping berupa pejalan kaki, kendaraan } \\
\text { parkir, kendaraan berhenti dam kendaraan masuk + keluar pada lajur } \\
\text { khusus sepeda motor }\end{array}$ & 0,4073 & Valid \\
\hline
\end{tabular}

Tabel 3. Uji validitas pernyataan kepentingan/harapan terhadap lajur khusus sepeda motor

\begin{tabular}{|c|l|c|c|}
\hline No & \multicolumn{1}{|c|}{ Pernyataan/Atribut } & r hitung & Hasil \\
\hline 1 & $\begin{array}{l}\text { Lebar Lajur Khusus Sepeda Motor dapat Menampung volume lalu } \\
\text { lintas kendaraan, Khususnya sepeda motor }\end{array}$ & 0,5842 & Valid \\
\hline
\end{tabular}




\begin{tabular}{|c|l|c|c|}
\hline 2 & $\begin{array}{l}\text { Lebar Lajur khusus sepeda motor dapat dipergunakan untuk menyiap } \\
\text { satu sepeda motor }\end{array}$ & 0,5957 & Valid \\
\hline 3 & $\begin{array}{l}\text { Tersedia rambu dan marka lalu lintas berupa informasi lokasi masuk- } \\
\text { keluar sepeda motor, batas kecepatan, rambu larangan berhenti dan } \\
\text { parkir pada lokasi-lokasi tertentu }\end{array}$ & 0,8040 & Valid \\
\hline 4 & $\begin{array}{l}\text { Rambu dan marka lalu lintas dipasang pada tempat-tempat yang } \\
\text { diperlukan dan mudah diperlihatkan }\end{array}$ & 0,7905 & Valid \\
\hline 5 & $\begin{array}{l}\text { Tersedia pemisah (separator) antara ajur khusus sepeda motor dari } \\
\text { jalan utama berupa marka lalu lintas atau kereb }\end{array}$ & 0,8160 & Valid \\
\hline 6 & $\begin{array}{l}\text { Kecepatan sepeda motor dapat mencapai 40 Km/Jam pada lajur } \\
\text { khusus sepeda motor }\end{array}$ & 0,6639 & Valid \\
\hline 7 & $\begin{array}{l}\text { Tidak terdapat jam-jam khusus (pembatasan) pelaksanaan lajur } \\
\text { khusus sepeda motor }\end{array}$ & 0,7171 & Valid \\
\hline 8 & $\begin{array}{l}\text { Tidak terjadi selip pada saat jaan basah atau ketika melewati penutup } \\
\text { lubang jalan }\end{array}$ & 0,7694 & Valid \\
\hline 9 & Tersedia pembatas lajur khusus sepeda motor (guard rail) & 0,6520 & Valid \\
\hline 10 & $\begin{array}{l}\text { Tidak terdapat hambatan samping berupa pejalan kaki, kendaraan } \\
\text { parkir, kendaraan berhenti dam kendaraan masuk + keluar pada lajur } \\
\text { khusus sepeda motor }\end{array}$ & 0,7120 & Valid \\
\hline 11 & $\begin{array}{l}\text { Permukaan jalan tidak bergelombang dan tidak berlubang serta tidak } \\
\text { terdapat kerusakan jalan lainnya pada lajur khusus sepeda motor }\end{array}$ & 0,7515 & Valid \\
\hline
\end{tabular}

Uji reliabilitas untuk penilaian kinerja terhadap lajur khusus sepeda motor menghasilkan nilai $\mathrm{r}_{11}$ sebesar 0,8609 dan untuk kepentingan/harapan terhadap lajur khusus sepeda motor menghasilkan nilai $\mathrm{r}_{11}$ sebesar 0,8917 . Dari hasil tersebut dapat disimpulkan bahwa pernyataan/atribut pada kuesioner dinyatakan reliable atau memenuhi uji realibilitas karena nilai $\mathrm{r}_{11}$ melebihi nilai $\mathrm{r}$ tabel. Selanjutnya dilakukan perhitungan tingkat kesesuaian (rasio) antara tingkat kepentingan dan penilaian terhadap kinerja pelayanan yang diberikan, serta perhitungan rata-rata bobot masingmasing atribut tingkat kepentingan dan penilaian kinerja pelayanan yang diberikan.

Tabel 4. Tingkat kesesuaian antara tingkat kinerja dan tingkat kepentingan

\begin{tabular}{|c|l|c|c|c|c|c|}
\hline No. & \multicolumn{1}{|c|}{ Atribut/Pernyataan } & $\begin{array}{c}\text { Bobot } \\
\text { kinerja }\end{array}$ & $\begin{array}{c}\text { Bobot } \\
\text { harapan }\end{array}$ & $\begin{array}{c}\text { Tingkat } \\
\text { kesesuaian }\end{array}$ & $\mathrm{X}$ & $\mathrm{Y}$ \\
\hline 1 & $\begin{array}{l}\text { Lebar lajur khusus sepeda motor dapat } \\
\text { menampung volume lalu lintas } \\
\text { kendaraan, khususnya sepeda motor }\end{array}$ & 394 & 360 & $109,44 \%$ & 3,94 & 3,60 \\
\hline 2 & $\begin{array}{l}\text { Lebar lajur khusus sepeda motor dapat } \\
\text { dipergunakan untuk menyiap satu } \\
\text { sepeda motor }\end{array}$ & 395 & 363 & $108,81 \%$ & 3,95 & 3,63 \\
\hline 3 & $\begin{array}{l}\text { Tersedia rambu dan marka lalu lintas } \\
\text { berupa informasi lokasi masuk-keluar } \\
\text { sepeda motor, batas kecepatan, rambu } \\
\text { larangan berhenti dan parkir pada } \\
\text { lokasi-lokasi tertentu }\end{array}$ & 357 & 429 & $83,21 \%$ & 3,57 & 4,29 \\
\hline 4 & $\begin{array}{l}\text { Rambu dan marka lalu lintas dipasang } \\
\text { pada tempat-tempat yang diperlukan } \\
\text { dan mudah diperlihatkan }\end{array}$ & 360 & 430 & $83,72 \%$ & 3,60 & 4,30 \\
\hline 5 & $\begin{array}{l}\text { Tersedia pemisah (separator) antara } \\
\text { ajur khusus sepeda motor dari jalan }\end{array}$ & 339 & 318 & $106,60 \%$ & 3,39 & 3,18 \\
\hline
\end{tabular}




\begin{tabular}{|c|l|c|c|c|c|c|}
\hline & $\begin{array}{l}\text { utama berupa marka lalu lintas atau } \\
\text { kereb }\end{array}$ & & & & & \\
\hline 6 & $\begin{array}{l}\text { Kecepatan sepeda motor dapat } \\
\text { mencapai 40 Km/Jam pada lajur khusus } \\
\text { sepeda motor }\end{array}$ & 374 & 390 & $95,89 \%$ & 3,74 & 3,90 \\
\hline 7 & $\begin{array}{l}\text { Tidak terdapat jam-jam khusus } \\
\text { (pembatasan) pelaksanaan lajur khusus } \\
\text { sepeda motor }\end{array}$ & 393 & 421 & $93,35 \%$ & 3,93 & 4,21 \\
\hline 8 & $\begin{array}{l}\text { Tidak terjadi selip pada saat jaan basah } \\
\text { atau ketika melewati penutup lubang } \\
\text { jalan }\end{array}$ & 363 & 429 & $84,62 \%$ & 3,63 & 4,29 \\
\hline 9 & $\begin{array}{l}\text { Tersedia pembatas lajur khusus sepeda } \\
\text { motor (guard rail) }\end{array}$ & 217 & 339 & $54,39 \%$ & 2,17 & 3,39 \\
\hline 10 & $\begin{array}{l}\text { Tidak terdapat hambatan samping } \\
\text { berupa pejalan kaki, kendaraan parkir, } \\
\text { kendaraan berhenti dam kendaraan } \\
\text { masuk + keluar pada lajur khusus } \\
\text { sepeda motor }\end{array}$ & 181 & 443 & $40,86 \%$ & 1,81 & 4,43 \\
\hline 11 & $\begin{array}{l}\text { Permukaan jalan tidak bergelombang } \\
\text { dan tidak berlubang serta tidak terdapat } \\
\text { kerusakan jalan lainnya pada lajur } \\
\text { khusus sepeda motor }\end{array}$ & 340 & 481 & $70,69 \%$ & 3,40 & 4,81 \\
\cline { 2 - 2 } & & & & & & \\
\hline
\end{tabular}

Kemudian kesebelas atribut tersebut dipetakan ke dalam diagram kartesius Importanceperformance analysis yang terbagi dalam empat kuadran pada Gambar 2.

1. Kuadran I (concrete these) menunjukkan bahwa atribut 10 masih belum sesuai dengan yang diharapkan oleh pengguna, sehingga jalan khusus sepeda motor seharusnya bisa terbebas dari hambatan samping, kendaraan parkir dan kendaraan berhenti pada lajur khusus sepeda motor.

2. Kuadran II (keep up the good work) menunjukkan bahwa atribut 3, atribut 4, atribut 7 , atribut 8 , dan atribut 11 sudah dianggap sesuai oleh para pengguna lajur lajur khusus sepeda motor. Akan tetapi faktor yang ada pada kuadran II ini harus tetap diperhatikan, karena faktor-faktor tersebut berpengaruh pada keselamatan para pengguna sepeda motor saat melintas di lajur khusus sepeda motor. Atribut yang ada pada kuadran II antara lain:

a. Tersedia rambu dan marka lalu lintas berupa informasi lokasi masuk-keluar sepeda motor, batas kecepatan, rambu larangan berhenti dan parkir pada lokasi-lokasi tertentu.

b. Rambu dan marka lalu lintas dipasang pada tempat-tempat yang diperlukan dan mudah diperlihatkan.

c. Tidak terdapat jam-jam khusus (pembatasan) pelaksanaan lajur khusus sepeda motor.

d. Tidak terjadi selip pada saat jalan basah atau ketika melewati penutup lubang jalan.

e. Permukaan jalan tidak bergelombang dan tidak berlubang serta tidak terdapat kerusakan jalan lainnya pada lajur khusus sepeda motor.

3. Kuadran III (low priority) menunjukkan bahwa atribut 9 merupakan atribut yang tidak terlalu signifikan bagi para pengguna lajur khusus sepeda motor. Sehingga atribut 9 
kinerjanya tidak terlalu berpengaruh pada lajur khusus sepeda motor tersebut. Atribut yang ada pada kuadran III ini ialah tersedia pembatas lajur khusus sepeda motor (guard rail).

4. Kuadran IV (possible overkill) menunjukan bahwa atribut 1, atribut 2, atribut 5, dan atribut 6 sudah dianggap memuaskan oleh para pengguna sepeda motor, Sehingga tidak perlu lagi ada perubahan yang besar untuk lajur khusus sepeda motor tersebut. Atribut yang ada pada kuadran IV diantara lain:

a. Lebar lajur khusus sepeda motor dapat menampung volume lalu lintas kendaraan, khususnya sepeda motor.

b. Lebar lajur khusus sepeda motor dapat dipergunakan untuk menyiap satu sepeda motor.

c. Tersedia pemisah (separator) antara ajur khusus sepeda motor dari jalan utama berupa marka lalu lintas.

d. Kecepatan sepeda motor dapat mencapai $40 \mathrm{~km} / \mathrm{jam}$ pada lajur khusus sepeda motor.

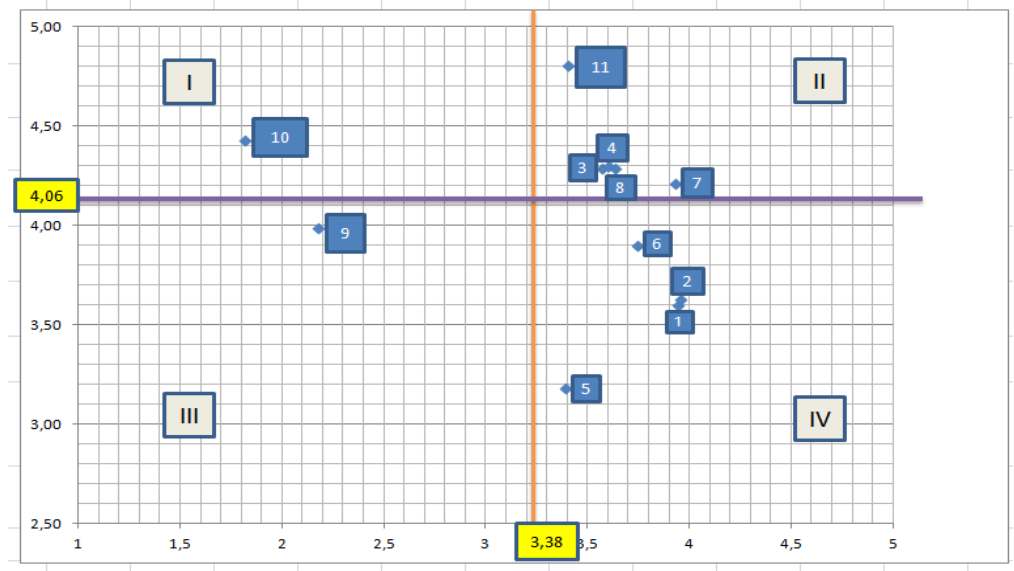

Gambar 2. Diagram kartesius hasil analisis IPA

\section{KESIMPULAN DAN SARAN}

Berdasarkan pemetaan antara tingkat kepentingan (importance) dan tingkat kinerja (performance) ke dalam diagram kartesius Importance performance analysis dapat diketahui bahwa lajur khusus sepeda motor pada Jalan Madan Merdeka Barat, DKI Jakarta memiliki permasalahan yang meliputi masih adanya hambatan samping, seperti kendaraan parkir dan kendaraan berhenti pada lajur tersebut. Berdasarkan analisis persepsi, kondisi ini belum memenuhi harapan dari pengguna lajur tersebut.

\section{DAFTAR PUSTAKA}

[1] Septiansyah, M.V.M. and Wulansari, D.N., 2018. Analisa Kinerja Ruas Jalan Medan Merdeka Barat, DKI Jakarta. Jurnal Kajian Teknik Sipil, 3(2), pp.110-115.

[2] Martilla, J. and James, J. (1977), Importance-Performance Analysis, Journal of Marketing, 41(1), 77-79.

[3] Sugiyono. 2010. Metode Penelitian Pendidikan. Bandung: Alfabeta.

[4] Syaodih Sukmadinata. 2009. Metode Penelitian Pendidikan. Bandung: PT. Remaja Rosdakarya.

[5] Guilford, J.P. (1956). Fundamental statistic in psychology and education. New York: McGraw Hill.

[6] Sevilla, Consuelo G. et. al (2007). Research Methods. Rex Printing Company. Quezon City. 